\title{
MECHANICAL PROPERTIES OF COMPOSITE BIOMASS BRIQUETTES
}

\author{
Aivars Kaķīis, Imants Nulle, Dainis Ancāns \\ Latvia University of Agriculture, Institute of Mechanics, Faculty of Engineering \\ J. Čakstes bulv. 5, Jelgava, LV 3001 \\ E-mail: Aivars.Kaķītis@1lu.lv; Imants.Nulle@1lu.lv; Dainis.Ancans@1lu.1v
}

\begin{abstract}
In the handling and usage processes, sufficient density and durability of biomass (straw, read) briquettes should be provided. For the briquettes density standards determined the value $\rho>1.0 \mathrm{~g} \cdot \mathrm{cm}^{-3}$. In the densification process usually fine grinded particles are used, what significantly increases energy consumption for stalk material cutting. Calculated energy consumption for common reed cutting to sizes less than $3 \mathrm{~mm}$ was $>7 \mathrm{~kJ} \mathrm{~kg}^{-1}$ but for size $20 \mathrm{~mm}$ it was approximately $1 \mathrm{~kJ} \mathrm{~kg}^{-1}$. The goal of the investigation was to obtain the necessary density and durability of briquettes of larger biomass particles by arranging them. The orientation of straw or reed stalks had to promote binding by the pressing operation. The long stalk linking, in the picture of coloured stalk briquettes sections, is good visible. Crushing force dependence on particle size for arranged structure briquettes is stated in laboratory experiments. The specific splitting force of arranged structure coarse chopped wheat straw and reed briquettes reaches value $35 \mathrm{~N} \mathrm{~mm}^{-1}$. It is approximately the same as industrially produced wood briquettes. Splitting force of the hemp stalk briquettes reaches $115 \mathrm{~N} \cdot \mathrm{mm}^{-1}$.
\end{abstract}

Keywords: stalk materials, biomass conditioning, biomass briquettes, durability.

\section{Introduction}

There are several herbaceous energy species, currently considered in Europe - miscanthus, red canary grass and switch-grass. Also as a biofuels provided for combustion include agricultural waste, forest residue, bark, common reed and peat.

Biofuels and especially - herbaceous biomass, contain more alkali metals (mainly potassium and sodium) than coal and peat. Alkali metals lower the ash melting point and upon reaction with chlorine, also contained in biomass, have a strong corrosive effect on heat exchangers [1]. Strategies for minimizing deposition problems include co-firing biofuels with "cleaner" fuels. Suitable "clean" fuels include certain types of coal or peat, which contain large amounts of inert species such as silica or alumina in their ash. By blending peat with chips or herbaceous biomass also sulphur content of the fuel is increased, sulphates are formed instead of chlorides, and the risk of corrosion is avoided [2].

Using peat with woody or herbaceous biomass has also other advantages - peat addition increases density and durability and lowers energy consumption for stalk material densification (briquetting, pelleting) [3, 4]. Particle size and shape are also of great importance for briquetting. It is generally agreed that biomass material of $6-8 \mathrm{~mm}$ size with $10-20 \%$ powdery component ( $<4$ mesh) gives the best results [5]. Calculated energy consumption for common reed cutting to mention size was $>5 \mathrm{~kJ} \mathrm{~kg}^{-1}$ but for size $20 \mathrm{~mm}$ it was approximately $1 \mathrm{~kJ} \mathrm{~kg}^{-1}[3]$.

The goal of the investigation was to obtain the necessary density and durability of reed-peat and straw-peat briquettes of larger biomass particles by arranging them. The orientation of straw or reed stalks had to promote binding by the pressing operation.

The basic standards for the solid biofuels developed Technical Committee - CEN/TC 335 Solid Biofuels. Standard EN 14961: Solid Biofuels - Fuel Specification and Classes determine the briquettes density $\rho=0.8-1.2 \mathrm{~g} \cdot \mathrm{cm}^{-3}$. The density of $\rho>1.0 \mathrm{~g} \cdot \mathrm{cm}^{-3}$ is recommendable for high quality wood briquettes. This value had been used for evaluation of herbaceous material densification results. 
To guarantee the quality of biomass briquettes in the handling and usage process, sufficient durability of briquettes have to be provided. In Latvia durability of solid biofuels briquettes is regulated by standard: Solid Biofuels - Methods for the determination of mechanical durability of pellets and briquettes - Part 2: Briquettes LVS EN 15210-2:2010. Here the durability is the measure of the resistance of densified fuels towards shocks and/or abrasion as a consequence of handling and transportation processes. The test sample is subjected to controlled shock by collision of briquettes against each other and against the walls of a defined rotating test chamber. The durability is calculated from the mass of sample remaining after separation of abraded and fine broken particles. The size of the sample shall conform to the requirements of corresponding technical specifications and shall be at least $15 \mathrm{~kg}$.

As the pressing operation with oriented stalks was carried out on laboratory equipment, productivity of it was low. Therefore durability of briquettes has to be characterized by different method where small amount of briquettes are sufficient.

In previous experiments shear strength of briquettes was examined. Shear strength tests were performed for determining ultimate shear tests for briquettes with particles size $0.5-3 \mathrm{~mm}$. Ultimate shear stress was determinated in direction perpendicular of briquetting direction [4]. Shear tests is not suitable for briquettes with particle length $50-300 \mathrm{~mm}$. For laboratory experimental testing of briquettes crushing strength should be examined [6,7].

For experimental testing wheat straw, hemp stalks, reed and reed composition with peat briquettes were produced by biomass pressing in closed die.

\section{Materials and methods}

Wheat straw, hemp stalks, reed and reed composition with peat biomass densification experiments had been carried out by means of hydraulic press equipment in closed die (Fig. 1). Pressure and piston displacement measurement data were collected on the PC using Picolog software. Chopped to different length stalks with moisture content $10 \%-14 \%$ was used for densification.

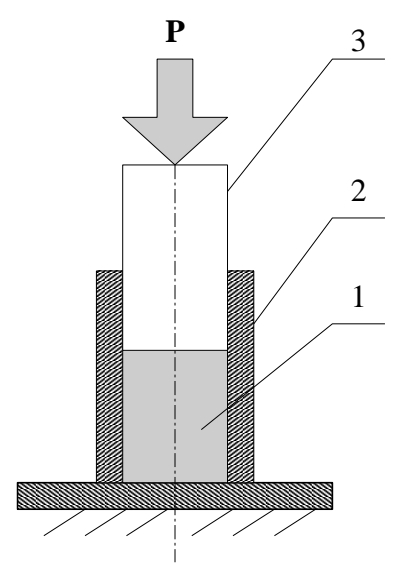

Fig. 1. Scheme of densification

1 - stalk material composition, 2 - closed die, 3 - piston

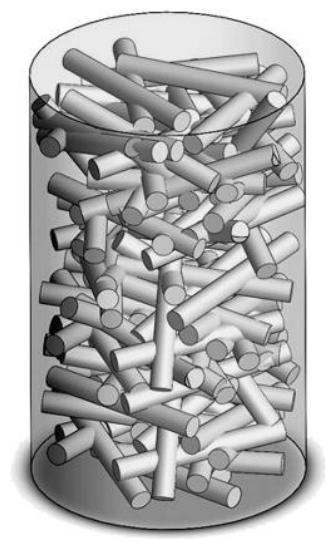

a

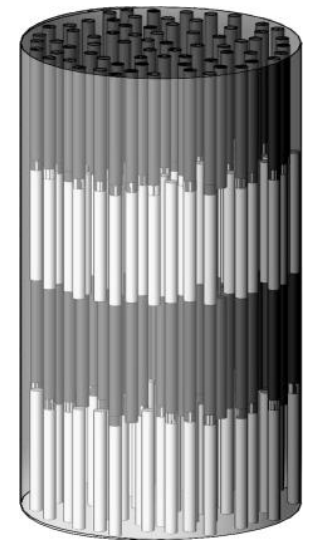

$\mathrm{b}$

Fig. 2. Arrangement of stalk material in closed die before briquetting

$\mathrm{a}$ - unarranged, $\mathrm{b}$ - arranged

Experimentally were tested briquettes of straw, reed and hemp stalks. Length of straw particles was 30, 60 and $100 \mathrm{~mm}$, reed stalks - 30, 60, 150 and $300 \mathrm{~mm}$ and hemp stalks - 150 and $300 \mathrm{~mm}$. Experiments was carried out with unarranged straw and reed stalks, arranged straw, reed and hemp stalks and with flattened and arranged reed stalks. Stalk flattening was performed with two rotating cylinders.

Stalk material particles with certain length was arranged in closed die as it is presented in Fig. 2b. Arranged particles were located in direction of longitudinal axe of die. Displacement 
between ends of particles in different layers was approximately from 5 to $15 \mathrm{~mm}$. Particles was slightly compacted in arranging process to obtain the same mass of material for every rerun. After arranging particles was compacted by hydraulic press with the maximum pressure $158 \mathrm{Mpa}$ for $62 \mathrm{~mm}$ diameter and $212 \mathrm{Mpa}$ for $36 \mathrm{~mm}$ diameter briquettes. Length, diameter of briquette and weight was measured. Density of briquettes was calculated on the basis of dimension measurement and weighing. For comparison $30 \mathrm{~mm}$ length straw and reed particles was placed in briquetting die without arranging (Fig. 2a) and pressed with maximum pressure $158 \mathrm{MPa}$.

Mechanical strength of the briquettes is characterized by the force necessary for its destruction $[5,7]$. The briquette of circular cross section is exposed to the pressure force as shown in Fig. 3, i.e. its direction is perpendicular to its axis of symmetry. Briquette was placed on support plate of testing machine and compression force $F$ was applied to briquette in the direction perpendicular of briquetting direction. This force is gradually increased until the briquette disintegration and splitting. The destruction force intensity was investigated for 11 samples of each composition. Obtained force - deformation diagrams (Fig. 4) were analyzed for all kinds of tested biomass and average crushing force was calculated.

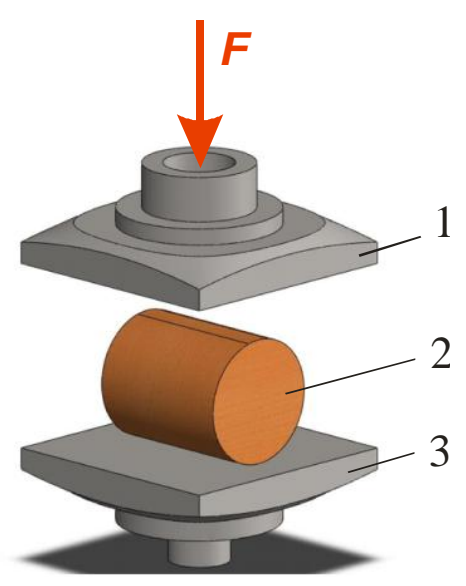

Fig. 3. Scheme of compression 1 - compression plate, 2 - briquette, 3 - support plate

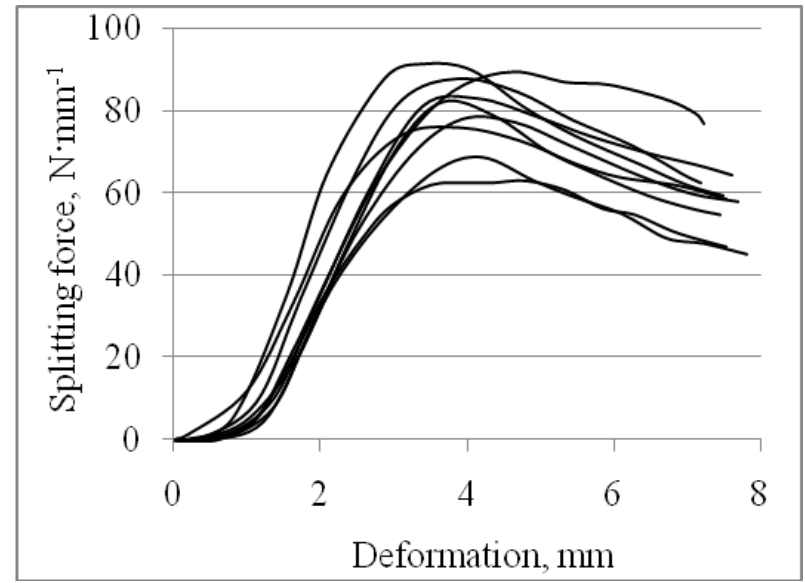

Fig. 4. Force - elongation diagram for not flattened reed stalks, $300 \mathrm{~mm}$ length

Diameter of briquettes produced in experimental pressing device was 36 and $62 \mathrm{~mm}$. Length of briquettes varies according closed die filling capacity before pressing. It depends on biomass stalk diameter, flattening and density. Average length of briquettes (diameter $62 \mathrm{~mm}$ ) was $60 \mathrm{~mm}$ and for diameter $36 \mathrm{~mm}$ length of briquettes varies from 34 to $85 \mathrm{~mm}$.

To compare durability of different length briquettes, specific splitting force was calculated:

$$
F_{s}=\frac{F}{L} \text {, }
$$

where $F_{s}$ - specific splitting force, $N \cdot m^{-1} ; F$ - splitting force, $N ; L$ - length of briquette, $m m$. Compression tests were carried out on Zwick and GUNT testing equipment. Zwick materials testing machine TC-FR2.5TN.D09 have force resolution 0.4\%, displacement resolution 0.1 $\mu \mathrm{m}$ and the maximal testing force $2.5 \mathrm{kN}$.

GUNT 20 materials testing machine have force resolution $1 \%$, displacement resolution $10 \mu \mathrm{m}$ and the maximal testing force $20 \mathrm{kN}$.

For comparison industrially produced wood briquettes and pure peat briquettes was tested in the same way. 


\section{Results and discussion}

In previous densification experiments of chopped straw, common reed stalk material particles and compositions with additives was stated that compacted with pressure $230 \mathrm{MPa}$ compositions of straw particles from two fineness groups $(2-3 \mathrm{~mm}$ and $<0.5 \mathrm{~mm})$ have density $>1.0 \mathrm{~g} \cdot \mathrm{cm}^{-3}$, if fineness proportion (amount of particles $<0.5$ ) exceed $25 \%$ [4]. Density $1.0 \mathrm{~g} \cdot \mathrm{cm}^{-3}$ has been obtained in densification of straw and reed stalk material particle compositions with peat, if peat proportion exceeds $20 \%$. Density of briquettes made from coarse chopped material (particle size more than $3 \mathrm{~mm}$ ) were significantly less than $1.0 \mathrm{~g} \cdot \mathrm{cm}^{-3}$. Fine communition of stalk material significantly increases energy of grinding. Increasing of particle length from 1 to $100 \mathrm{~mm}$ decreases specific cutting energy up to 40 times. Roughly shredded straw or reed material does not provide necessary density and durability of briquettes, if material is unarranged in the closed die before cold briquetting.

The scope of investigation was to find method how to increase density and durability of coarse chopped material briquettes. If particles are inserted in briquetting die without arranging they lay down perpendicularly of pressing direction. Pressing force compact particles, but sharp adhesion between them does not occur because of hard and glossy outside surface of the stalks. To confirm this hypothesis experimental test was carried out. Reed stalk particles were arranged in perpendicular layers (Fig. 5) and compressed between two flat surfaces. Length of particles was $50 \mathrm{~mm}$, pressing force $300 \mathrm{kN}$. After sample of stalks was released adhesive force between them was not stated.

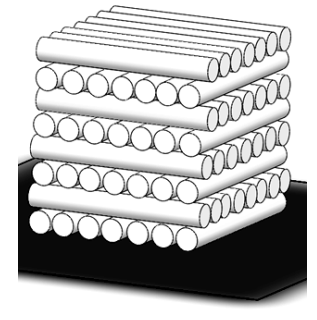

a

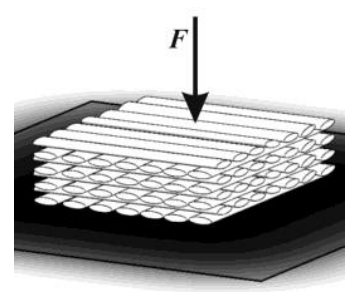

b

Fig. 5. Pressing process of perpendicularly arranged reed particles $\mathrm{a}-$ arrangement of particles before pressing, $\mathrm{b}$ - pressing process

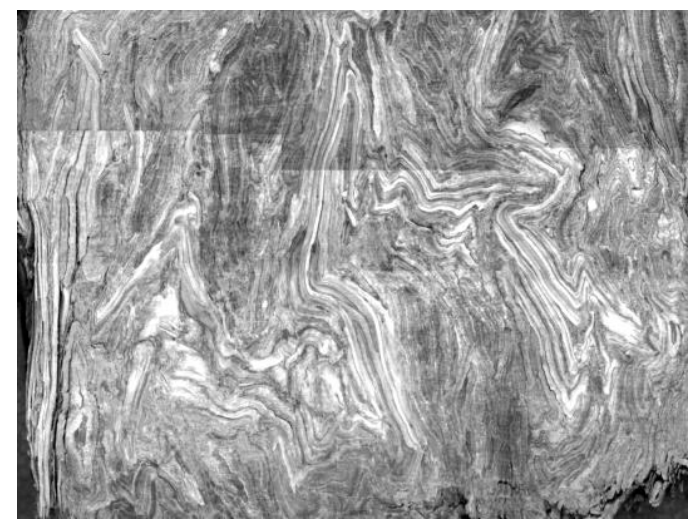

Fig. 6. Cross-section of reed stalk briquette with colour particles

To increase density and strength of briquettes necessary maximize bonding surface area between particles. Suitable arrangement of straw and reed particles in briquetting die allows changing deformation directions of particles. The stalk material curves and adhesion between particles increases (Fig. 6).

Arranged particles were located in direction of longitudinal axe of die according Fig. $2 \mathrm{~b}$. Displacement between ends of particles in different layers was approximately from 5 to $15 \mathrm{~mm}$. Particles were slightly compacted in arranging process to obtain the same mass of material for every rerun.

Results of investigation of briquettes density dependence on arranged particle size is presented in Fig. 7. Increasing particle length from 30 to $100 \mathrm{~mm}$ does not affect significantly density of briquettes if diameter of briquettes is $62 \mathrm{~mm}$. Density of arranged straw briquettes varies between $939 \mathrm{~kg} \cdot \mathrm{m}^{-3}(100 \mathrm{~mm})$ and $928 \mathrm{~kg} \cdot \mathrm{m}^{-3}(30 \mathrm{~mm})$. It is less then recommended $1.0 \mathrm{~g} \cdot \mathrm{cm}^{-3}$ and dependence on the length is less than $1.3 \%$.

Density of arranged reed briquettes varies between $927 \mathrm{~kg} \cdot \mathrm{m}^{-3}$ (length of particles $30 \mathrm{~mm}$ ) and $947 \mathrm{~kg} \cdot \mathrm{m}^{-3}(60 \mathrm{~mm})$. Density dependence on the particle length for reed briquettes does not 
exceed $3 \%$. The density of flattened reed stalks briquettes is $>1000 \mathrm{~kg} \cdot \mathrm{m}^{-3}$. It shows that arranging and previously densification has good influence on briquettes density.

The addition of peat to wheat straw and reed particles increases density of briquettes. Fig. 8 presents the changes of briquettes density depending on peat content. The addition of $30 \%$ peat increases density of briquettes till $\sim 1000 \mathrm{~kg} \cdot \mathrm{m}^{-3}$. Significant reed+peat briquettes density depending on material length was not stated (Fig. 8).

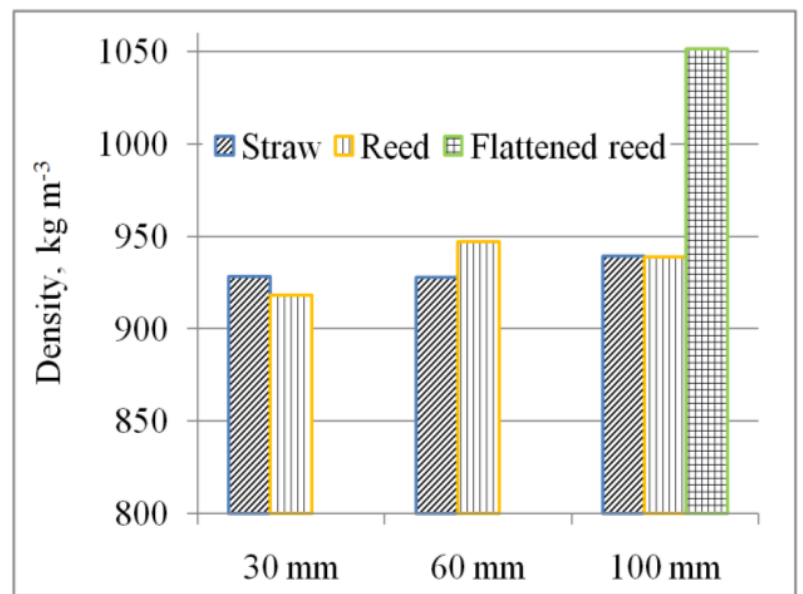

Fig. 7. Briquette density dependence on the length of particles

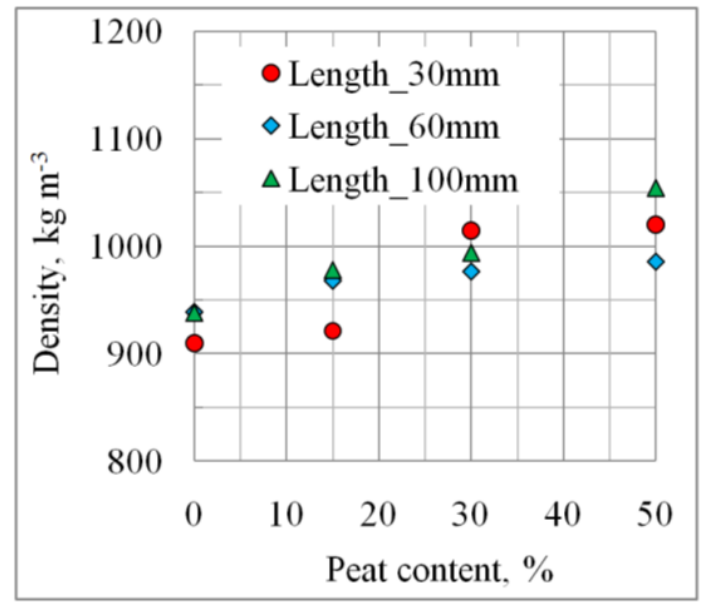

Fig. 8. Briquette density dependence on the peat content

Density investigation for briquettes with diameter $36 \mathrm{~mm}$ were carried out for different length of reed and hemp particles. Increasing no flattened reed particle length from 100 to $300 \mathrm{~mm}$ increases density of briquettes from 1060 to $1130 \mathrm{~kg} \cdot \mathrm{m}^{-3}$ (Fig. 9). It is equal with density of reed - peat composition briquettes with peat content $50 \%$ (Fig. 8)

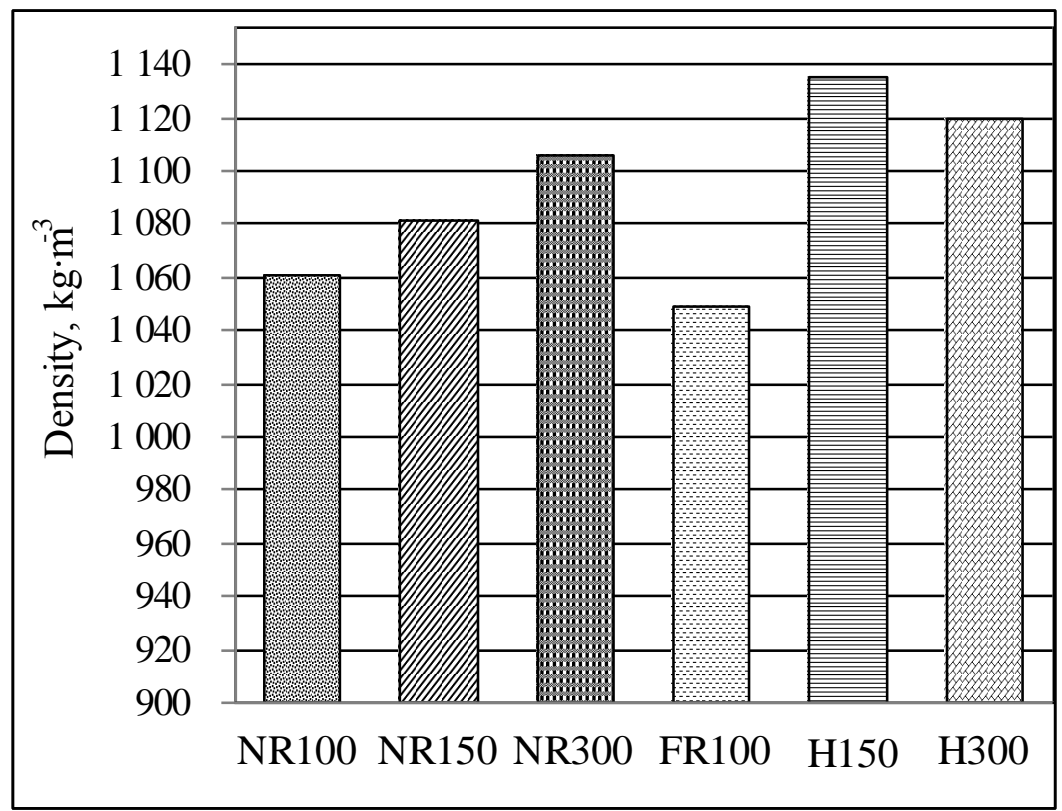

NR100 - not flattened reed, length $100 \mathrm{~mm}$ NR150 - not flattened reed, length $150 \mathrm{~mm}$ NR300 - not flattened reed, length $300 \mathrm{~mm}$ FR100 - flattened reed, length $100 \mathrm{~mm}$ H150 - hemp stalks, length $150 \mathrm{~mm}$ H300 - hemp stalks, length $300 \mathrm{~mm}$

Fig. 9. Density of briquettes with diameter $36 \mathrm{~mm}$

Density of flattened reed briquettes is equal for both diameter briquettes. Density of hemp stalk briquettes significantly exceeds recommend $1000 \mathrm{~kg} \cdot \mathrm{m}^{-3}$ and reaches $1135 \mathrm{~kg} \cdot \mathrm{m}^{-3}$. 
Durability test was carried out using ZWICK and GUNT material testing equipment. Diameter of closed dies for briquetting was 60 and $35 \mathrm{~mm}$ which let obtain briquettes with diameters accordingly 62 and $36 \mathrm{~mm}$. As a result of tests briquette splitting force dependence on briquette deformation was stated (Fig. 4). Evaluation of average splitting force for all reruns stated dependence of disintegration force on the particle length.

Fig. 10 presents dependence of the splitting force on the particle length for wheat straw and reed made from arranged structure briquettes. Increasing of durability by increasing of particle length was stated for reed briquettes, but for straw briquettes change of splitting force was not significant. Comparing unarranged reed stalks (length $30 \mathrm{~mm}$ ) briquettes showed low specific destruction resistance $6 \mathrm{~N} \cdot \mathrm{mm}^{-1}$. Briquettes from flattened and arranged reed stalks showed good results. The splitting force of briquettes was 1.3 times higher than for not flattened stalk briquettes. Splitting force represented in Fig. 10 was stated for briquettes with diameter $62 \mathrm{~mm}$.

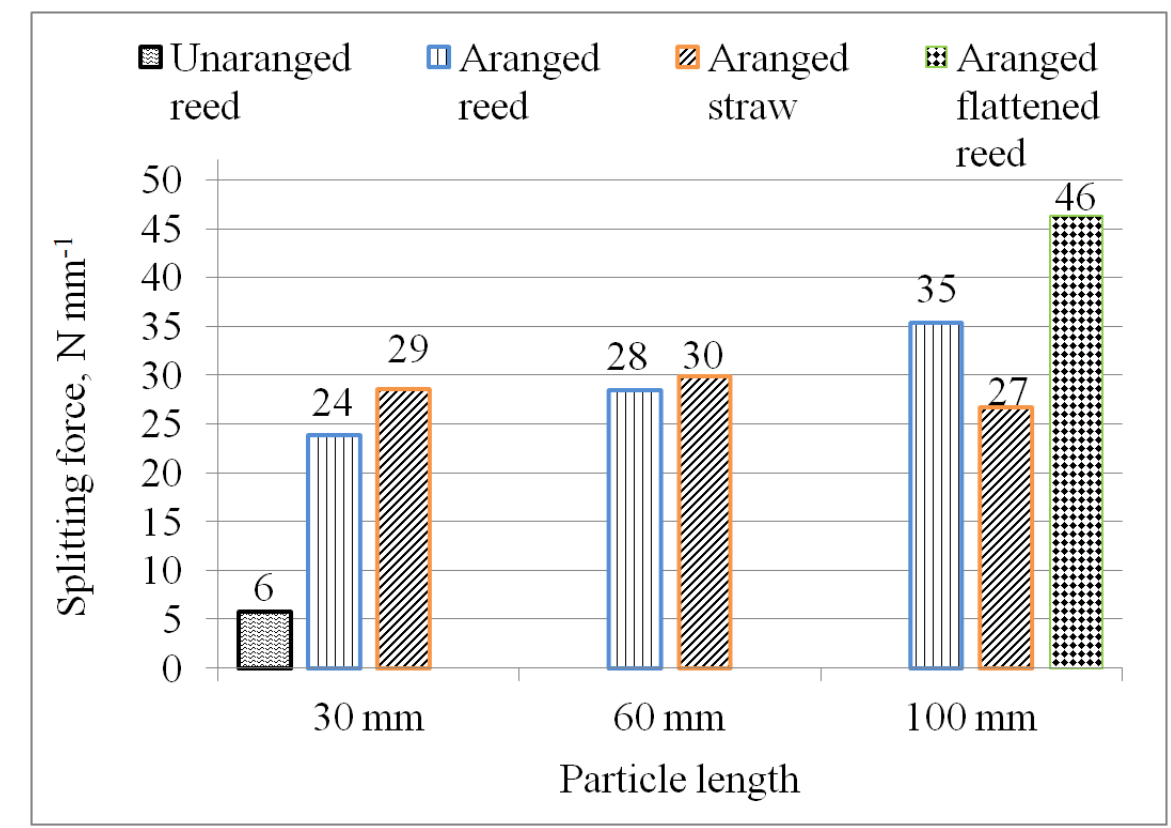

Fig. 10. Dependence of specific splitting force on particle length for straw and reed briquettes with diameter $62 \mathrm{~mm}$

Peat additives let substantially increase splitting force of reed briquettes (Fig. 11). The addition of $15 \%$ peat increases durability of briquettes from 1.2 to 1.3 times for all lengths of particles. Increasing addition of peat till $30 \%$ and more, increases durability of briquettes, but splitting force dependence on particles length is not significant (Fig. 11). 


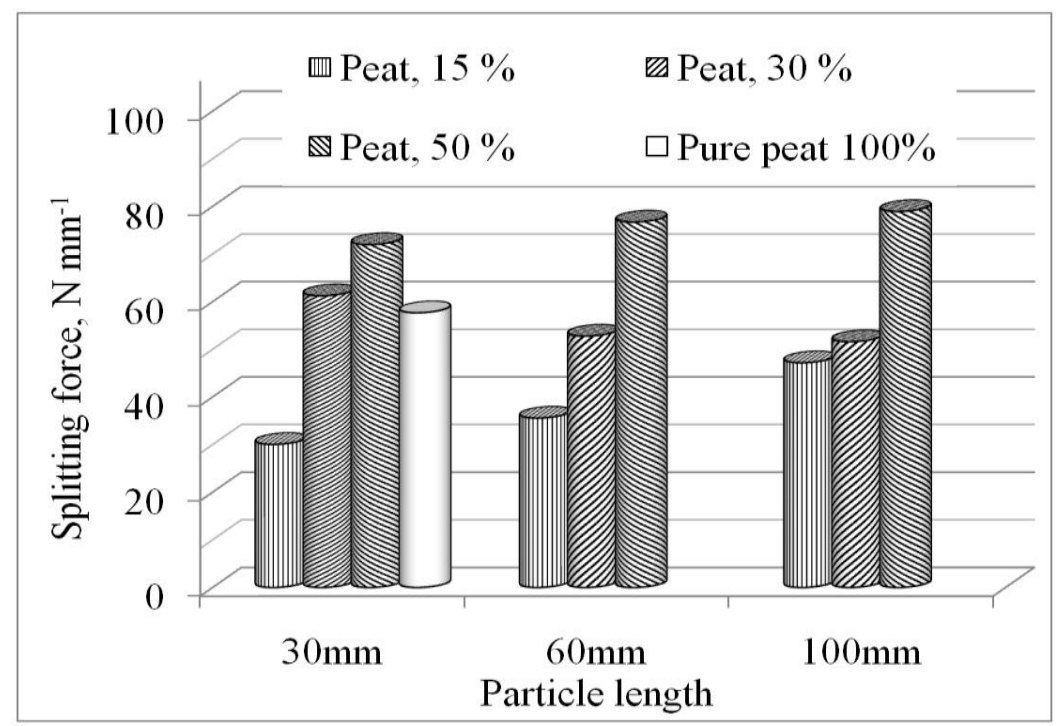

Fig. 11. Specific splitting force dependence on peat additive for reed+peat compositions (diameter of briquettes $62 \mathrm{~mm}$ )

For comparison industrially produced wood, unarranged reed and wheat straw and pure peat briquettes were tested using the same method. Specific splitting force for wood briquettes reaches $38 \mathrm{~N} \cdot \mathrm{mm}^{-1}$ and this value can be taken as a base for comparison of experimentally made briquettes. Pure peat briquettes showed splitting force $55 \mathrm{~N} \cdot \mathrm{mm}^{-1}$.

Unarranged reed particle (length $30 \mathrm{~mm}$ ) briquettes show specific splitting force approximately $6 \mathrm{~N} \cdot \mathrm{mm}^{-1}$. The same value of splitting force was obtained for wheat straw (30 $\mathrm{mm}$ ) unarranged briquettes destroying.

Splitting force for briquettes with diameter $36 \mathrm{~mm}$ was stated for different particle length of reed and hemp stalks (Fig. 12).

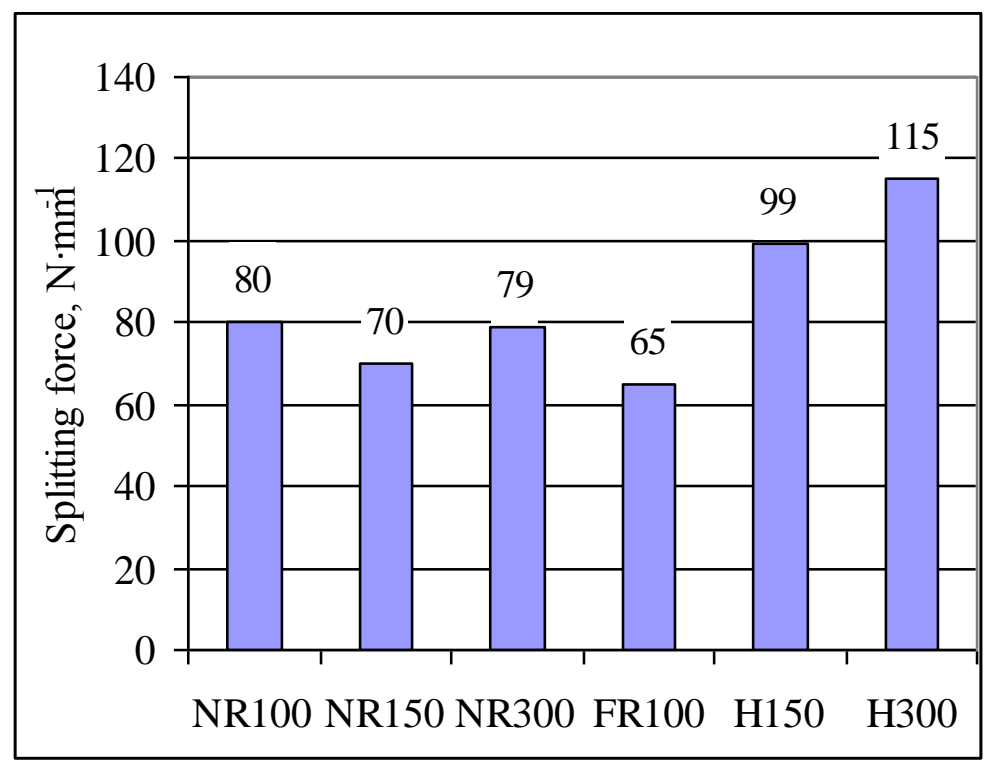

NR100 - not flattened reed, length $100 \mathrm{~mm}$

NR150 - not flattened reed, length $150 \mathrm{~mm}$

NR300 - not flattened reed, length $300 \mathrm{~mm}$

FR100 - flattened reed, length $100 \mathrm{~mm}$

H150 - hemp stalks, length $150 \mathrm{~mm}$

H300 - hemp stalks, length $300 \mathrm{~mm}$

Fig. 12. Specific splitting force for briquettes with diameter $36 \mathbf{~ m m}$

Splitting force of no flattened reed particles varies from 70 to $80 \mathrm{~N} \cdot \mathrm{m}^{-1}$. The same value of splitting force was stated for reed - peat briquettes with diameter $62 \mathrm{~mm}$, if peat content reaches 50\% (Fig. 11). Splitting force stated for pure reed stalk briquettes with particle length 
$100 \mathrm{~mm}$ (diameter $62 \mathrm{~mm}$ ) was only $35 \mathrm{~N} \cdot \mathrm{m}^{-1}$ (Fig. 10). Reed stalk flattening decreases splitting force compared together with no flattened reed stalks till $65 \mathrm{~N} \cdot \mathrm{m}^{-1}$ (Fig. 12).

Significant increasing of splitting force was stated for hemp stalk briquettes. Splitting force for hemp stalk particles with $300 \mathrm{~mm}$ length reaches $115 \mathrm{~N} \cdot \mathrm{m}^{-1}$.

\section{Conclusions}

1. Addition of $30 \%$ peat to coarse chopped straw or reed arranged structure briquettes increases density to recommended value $1.0 \mathrm{~g} \cdot \mathrm{cm}^{-3}$. Decreasing of the diameter of the briquette let exceed recommended density for pure reed and hemp stalk briquettes. Density of the hemp stalk briquettes reaches $1135 \mathrm{~kg} \cdot \mathrm{m}^{-3}$ for particle length $300 \mathrm{~mm}$.

2. Increasing peat proportion in arranged structure straw and reed briquettes till $50 \%$ increases splitting force $2-3$ times.

3. Destroying force of arranged structure coarse chopped wheat straw and reed briquettes with diameter $62 \mathrm{~mm}$ reaches value $35 \mathrm{~N} \cdot \mathrm{mm}^{-1}$. It is approximately the same as industrially produced wood briquettes.

4. Decreasing of the diameter of the briquettes from 62 to $36 \mathrm{~mm}$ increases splitting force of the pure reed stalk briquettes approximately 2 times.

5. Arranged structure of biomass particles in briquetting die is recommended for significant increasing durability of stalk material briquettes.

6. Flattening of the herbaceous biomass stalks before briquetting arranged briquettes increases density of the $62 \mathrm{~mm}$ diameter briquettes to more than $1.0 \mathrm{~g} \cdot \mathrm{cm}^{-3}$ and splitting force 1.3 times.

\section{References}

1. Kavalov B., Peteves D. Bioheat applications in the European Union: An analysis and perspective for 2010. Luxembourg: Office for Official Publications of the European Communities, 2004. 122 p. ISBN 92-8948730-5.

2. Alakangas E., Agar D., Leppänen M. Report of the seminar presentations and study tour [online]. Biomass Logistics and Combustion [viewed 2011-01-15]. Accessible: http://www.opetchp.net/download/wp3/summerschoolreport.pdf

3. Kronbergs E., Kakitis A., Smits M., Nulle I. Biomass conditioning for solid biofuel compositions. In: Proceedings of 2nd International Baltic Bioenergy Conference. Germany, Fachhochschule Stralsund University of Applied Sciences. Stralsund: LAiV, 2006, p. 81 - 90.

4. Kakitis A., Nulle I. Durability of stalk material briquettes. In: Proceedings of the International conference "Scientific achievements for wellbeing and development of society", March 4-5, 2004,- Rēzekne, pp. 26 31.

5. Grover P.D., Michra S.K. Biomass briquetting: Technology and practices. Bangkok: FAO Regional Wood Energy Development Programme in Asia, 1996. 48 p.

6. Plištil D., Brožek M., Malaták J., Hutla P. (2005): Mechanical characteristics of standard fuel briquettes on biomass basic. Research in Agricultural Engineering, 51: 66-72.

7. Brožek M., 2001. Briketování nekovového odpadu. In: Sborník z mezinárodní konference XIV Diamatech.Krakow, Univerzita Radom: 84-87.

Anotācija. Transportēšanas un lietošanas apstākļos biomasu (salmu, niedru, kaņepju stiebru) briketēm ir nepieciešams nodrošināt pietiekamu blīvumu un mehānisku izturību. Standartos rekomendētais brikešu blīvums ir $\rho>1.0 \mathrm{~g} \cdot \mathrm{cm}^{-3}$. Gan granulu, gan brikešu ražošanā, stiebru smalcināšana ir viens no energoietilpīgākajiem procesiem. Tāpēc lietderīgi izvēlēties atbilstošo stiebru masas daļiņu smalcināšanas pakāpi atkarībā no izgatavošanas tehnologijas. Tā kā granulu diametrs ir robežās no aptuveni $4 \mathrm{~mm} l \bar{l} d z 25 \mathrm{~mm}$, tad ir nepieciešama ļoti smalka smalcināšana un tas nozīmē, ka tiek patērēta liela energija produkta ražošanas sākuma stadijā. Iepriekš veiktajos eksperimentos tika konstatēts, ka niedru smalcināšanas energija, ja daļiņu lielums nepārsniedz $3 \mathrm{~mm}$, ir $>7 \mathrm{~kJ} \cdot \mathrm{kg}^{-1}$, bet $20 \mathrm{~mm}$ daļiņu lielumam enerǵijas patēriņš bija aptuveni $1 \mathrm{~kJ} \cdot \mathrm{kg}^{-1}$. Pētījuma mērķis ir sasniegt nepieciešamo blīvumu un mehānisko noturību ar sakārtotām, 30 līdz $300 \mathrm{~mm}$ garām, biomasas daļiņām. Sakārtoti salmu un niedru stiebri nodrošina to savstarpējo saķeri kompaktēšanas procesā. Garu stiebru saistī̌̌anās labi redzama iekrāsotu stiebru daļiņu briketes šķēersgriezumā. 
Pētījumi tika veikti ar sakārtotas struktūras, rupji smalcinātu kviešu salmu, niedru un kaņepju stiebru briketēm. Briketes tika izgatavotas presējot doto biomasu metāla cilindrā. Tika izgatavotas divu izmēru briketes, ar diametru $62 \mathrm{~mm}$ un $36 \mathrm{~mm}$. Briketēšanas spiediens - attiecīgi 158 un $212 \mathrm{Mpa}$.

Laboratorijas eksperimentos veikti sakārtotas struktūras brikešu mehāniskās izturības pārbaude. Rupji smalcinātu kviešu salmu un niedru brikešu īpatnējais sagraušanas spēks sasniedza $35 \mathrm{~N} \cdot \mathrm{mm}^{-1}$, kas ir aptuveni tāds pats kā rūpnieciski ražotai kokskaidu briketei. Kaņepju stiebru brikešu ìpatnējais sagraušanas spēks sasniedza $115 \mathrm{~N} \cdot \mathrm{mm}^{-1}$. Lai uzlabotu salmu un niedru brikešu sadegšanas īpašĭbas un samazinātu korozijas risku kurtuvju elementiem, rekomendējama kūdras pievienošana brikešu sastāvam. Eksperimentāli tika noteikta kompozītu brikě̌u (niedres + kūdra) noturība. Šādu brikě̌u blīvums pārsniedza rekomendējamo $1.0 \mathrm{~g} \cdot \mathrm{cm}^{-3}$. Brikešu sagraušanas spēks, atkarībā no dalinnu izmēra, bija robežās no 70 līdz $78 \mathrm{~N} \cdot \mathrm{m}^{-1}$. 